\title{
記憶・学習モデルとしての長期シナプス伝達増強 および抑制における一酸化窒素の関与
}

$\begin{array}{llll}\text { 上 㟝 善 規* } & \text { 森 脇 裕 平* 小 村 秀 史* } \\ \text { 和 田 孝一郎* } & \text { 伊 藤 忠 雄* }\end{array}$

記憶・学習のモデルとして，海馬の長期シナ プス伝達増強（LTP）や，小脳の長期シナプス 伝達抑制（LTD）が研究され，特に，一酸化窒 素（NO）がこれらの成立に関与している可能性 が示唆されている ${ }^{1,2)}$. 海馬では，テタヌス刺 激により LTPが形成される際，刺激を受けたポ スト側の細胞からNOが合成・遊離され，これが 逆行性メッセンジャーとして拡散して，プレ側 の神経終末からのグルタミン酸 （Glu）遊離を 促進するとされている．また，小脳では登上線 維刺激によりNOが遊離され，同様にこれが平行 線維のシナプスからのGlu遊離を抑制して, LTD を形成するとされている。一方，最近，種々の NO合成酵素阻害薬, NO遊離薬, NO除去薬が開発 されて来ている. 従って,このNOのLTPやLTDに おける作用を明確にすることにより，これらNO 関連薬が中枢神経系に影響を与える可能性を検 討した。

方法：ウイスター系雄性ラット（体重200g) の海馬, 小脳を, 20倍量の庶糖溶液でホモゲナ イズし，18\%フィコール溶液中で遠心し，通常 -大型神経終末 (P2・P3) シナプトソーム分画 を得, フィルター上で酸素を飽和させたクレブ ス・リンゲル液により灌流した ${ }^{3)}$. 30分のプレ インキュベーション後, 必要によりNOを遊離す るニトロプルシド等の薬物をクレブス液に混在 させた．灌流開始40分後に，脱分極刺激を 30 $\mathrm{mM} \mathrm{KCl} よ り 2$ 分間与えた。遊離されたアミノ

\footnotetext{
* 鳥取大学医学部臨床薬理 于 683 米子市西町 86
}

は5-アミノ吉草酸を内部標準として加え, オル トフタルアルデヒドで蛍光誘導体に变換後, 逆 相カラムにより分離定量した ${ }^{4,5)}$.

結果：海馬の通常, 大型神経終末および薄切 片からは非刺激時にそれぞれ $\mathrm{mg}$ タンパク当り毎 分 104, 85, 64 ピコ壬ルのGlu が遊離し, 脱分 極刺激時には，その遊離が3.6，4.5，2.2 倍に 増加した．灌流液にニトロプルシドを混在させ ても, 非刺激時, 脱分極刺激時のP2・P3シナプ トソームからの Gluの遊離には影響しなかった が, 薄切片からの遊離増加は約 1.7倍になった。 海馬からのアスパラギン酸（Asp）の遊離はGlu

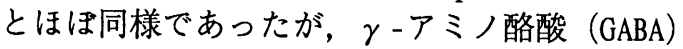
の遊離はニトロプルシドの影響を受けなかった (Tab) ${ }^{6)}$.

一方，小脳の通常および大型神経終末からの 非刺激時のGlu遊離はそれぞれ 101，84ピコモ ルで，脱分極刺激により，2.3，4.1倍に増加し た。同様にニトロプルシドを灌流液に加えた場 合, 通常型シナプトソームからの Glu遊離は変 化しなかったが，大型シナプトソームからの遊 離は脱分極刺激時にその増加分の約 $50 \%$ を抑制 した。海馬と同様に，小脳神経終末からの Asp 遊離は Glu遊離に類似し，GABA遊離は影響され なかった（Tab）。

またこれらニトロプルシドの作用は, 膜透過 性サイクリックGMP の灌流でも同様の結果が得 られた.さらに，NOによる可溶型グアニル酸シ クラーゼの活性化抑制薬であるメチレン・ブル 一の混在によってニトルプルシドの作用が減弱 した。 
Tab. ラット海馬・小脳からの脱分極刺激アミノ酸遊離に対する一酸化窒素の影響

\begin{tabular}{|c|c|c|c|c|}
\hline & & グルタミン酸 & アスパラギン酸 & $\gamma$-アミノ酪酸 \\
\hline \multicolumn{5}{|l|}{ 海馬 } \\
\hline \multirow[t]{3}{*}{ 通常型シナプトソーム } & コントロール & $267 \pm 14$ & $36 \pm 3$ & $32 \pm 4$ \\
\hline & ニトロプルシド & $263 \pm 21$ & $36 \pm 4$ & $31 \pm 6$ \\
\hline & サイクリックGMP & $283 \pm 15$ & $37 \pm 6$ & $35 \pm 3$ \\
\hline \multirow[t]{3}{*}{ 大型シナプトソーム } & コントロール & $300 \pm 25$ & $60 \pm 5$ & $31 \pm 3$ \\
\hline & ニトロプルシド & $296 \pm 13$ & $58 \pm 4$ & $30 \pm 3$ \\
\hline & サイクリックGMP & $294 \pm 25$ & $59 \pm 5$ & $30 \pm 5$ \\
\hline \multirow[t]{3}{*}{ 荨切片 } & コントロール & $75 \pm 9$ & $8 \pm 1$ & $22 \pm 3$ \\
\hline & ニトロプルシド & $128 \pm 10^{\circ}$ & $16 \pm 1^{\circ}$ & $23 \pm 3$ \\
\hline & サイクリックGMP & $117 \pm 4^{*}$ & $15 \pm 2^{\circ}$ & $22 \pm 3$ \\
\hline \multicolumn{5}{|l|}{ 小脳 } \\
\hline \multirow[t]{2}{*}{ 通常型シナプトソーム } & コントロール & $133 \pm 12$ & $40 \pm 5$ & $13 \pm 2$ \\
\hline & ニトロプルシド & $128 \pm 10$ & $45 \pm 5$ & $13 \pm 2$ \\
\hline \multirow[t]{3}{*}{ 大型シナプトソーム } & コントロール & $255 \pm 20$ & $46 \pm 7$ & $30 \pm 4$ \\
\hline & ニトロプルシド & $120 \pm 23^{\circ}$ & $31 \pm 5^{\circ}$ & $29 \pm 6$ \\
\hline & サイクリックGMP & $157 \pm 27^{\circ}$ & $34 \pm 8$ & $29 \pm 4$ \\
\hline
\end{tabular}

脱分極刺激による遊離增加アミノ酸 (means $\pm \mathrm{SE}, \mathrm{pmol} / \mathrm{min} / \mathrm{mg}$ タンパク)

• $P<0.01$ vs. コントロール

考察：NOは海馬の神経終末には直接作用しな いものの,グリアやショート・ニューロンを介 して LTP形成に重要な役割を果たしていた。ま た，小脳では，P3シナプトソームは苔状線維終 末を多く含むことから，この神経終末にNOが直 接作用し, Glu 遊離抑制作用を示した。ささらに, P2シナプトソーム分画は平行線維終末を含むた め,これとプルキニエ細胞間のシナプス伝達の 制御には，海馬と同様に，グリア等の介入が必 要で, NOが直接神経終末に作用しないことが示 唆された.

結論：以上より，NOは神経系のシナプス伝達 や，その可塑性に関与しているため, N0関連薬 が記憶・学習といった中枢神経系の基本的機能 に影響を与える可能性が考えられた。 今後, 記 憶障害などの病態との関連性を検討したい.

\section{文 献}

1) Bliss T. V. P., and Collingridge G. L.: A synaptic model of memory: long-term potentiation in the hippocampus. Nature, 361: 31-39 (1993).

2) Shibuki K., and Okada D.: Endogenous nitric oxide release required for long-term synaptic depression in the cerebellum. Nature, 349: 326-328 (1991).

3) Kamisaki Y., Hamahashi T., Mita C., and Itoh T.: D-2 Dopamine receptors inhibit release of aspartate and glutamate in rat retina. J. Pharmacol. Exp. Ther., 256: 634-638 (1991).

4) Kamisaki Y., Takao Y., Itoh T., Shimomura T., Takahashi K., Uehara N., Yoshino Y.: Determination of gamma-aminobutyric acid in human cerebrospinal fluid by isocratic high-performance liquid chromatography. J. Chromatogr., 529: 417-423 (1990).

5) Kamisaki Y., Maeda K., Ishimura M., Omura H., and Itoh T.: Effects of taurine on depolarizationevoked release of amino acids from rat cortical synaptosomes. Brain Res., 627: 181-185 (1993).

6) Kamisaki Y., Maeda K., Ishimura M., Omura H., Moriwaki Y., and Itoh T.: No enhancement by nitric oxide of glutamte release from P2 and P3 synaptosomes of rat hippocampus. Brain Res., 644: 128-134 (1994). 